\title{
Effect of Salinity on Evaporation and the Water Cycle
}

\author{
J. I. Obianyo ${ }^{a^{*}}$ \\ ${ }^{a}$ Department of Civil Engineering, Michael Okpara University of Agriculture, Umudike, Abia State, Nigeria
}

\begin{abstract}
This study is on the effect of salinity on evaporation from water bodies and its probable influence on the water cycle. Five different salts were used in this study. Different concentrations of Magnesium Sulphate, Sodium Hydroxide, Sodium Chloride, Ammonium Chloride, and Potassium Nitrate solutions in the neighbourhood of $0.04,0.08,0.12,0.16,0.20$, and $0.24 \mathrm{~g} / \mathrm{cm}^{3}$ were prepared by dissolving 20,40,60,80,100, and $120 \mathrm{~g}$ weights of these salts in $500 \mathrm{~cm}^{3}$ of distilled water. The first evaporation could contain only $500 \mathrm{~cm}^{3}$ of distilled water and served as the control experiment. The solutions were introduced into evaporation cans, each with a capacity of $700 \mathrm{~cm}^{3}$, stored at room temperature, and evaporation was allowed to take place. Evaporation from the cans was measured at 24 hour intervals for a period of 14 days. Results showed that in all salts, as salinity increases, evaporation is reduced. On the 10th day, evaporation retardation factors for Magnesium Sulphate, Sodium Hydroxide, Sodium Chloride, Ammonium Chloride, and Potassium Nitrate were found to be $0.800,0.490,0.712,0.820$, and 0.822 , respectively. Ratios of evaporation retardation factors were 1:1.6327 for Sodium Hydroxide: Magnesium Sulphate; 1:1.4531 for Sodium Hydroxide: Sodium Chloride; 1:1.6735 for Sodium Hydroxide: Magnesium Sulphate; 1:1.4531 for Sodium Hydroxide: Sodium Chloride; 1:1.6327 for Sodium Hydroxide: Ammonium Chloride and 1:1.6776 for Sodium Hydroxide: Potassium Nitrate solutions. The highest evaporation took place in Potassium Nitrate solution at an ultimate concentration of $0.24 \mathrm{~g} / \mathrm{cm}^{3}$. This was followed by Ammonium Chloride, Magnesium Sulphate, Sodium Chloride and Sodium Hydroxide. This salinity effect will impact on the outflow parameter in the water cycle with a consequent reduction in evaporation, which reduces precipitation. Hence, the formation of rain in the cloud will be inhibited and ultimately lead to climate change.
\end{abstract}

Keywords:

Salinity;

Evaporation;

Water Cycle;

Effect.

$\begin{array}{llll}\text { Received: } & 04 & \text { May } & 2019 \\ \text { Accepted: } & 19 & \text { July } & 2019\end{array}$

\section{1- Introduction}

Ocean evaporation $(\mathrm{E})$ and precipitation $(\mathrm{P})$ are the fundamental components of the global water cycle. They are also the freshwater flux forcing (i.e., E-P) for the open sea salinity. The apparent connection between ocean salinity and the global water cycle leads to the proposition of using the oceans as a rain gauge. However, the exact relationship between E-P and salinity is governed by complex upper ocean dynamics, which may complicate the interface of the water cycle from salinity observations. Evaporation from the ocean and precipitation into the ocean are the primary sources (86\%) and sinks $(78 \%)$ of the atmospheric water vapour and, accordingly, the major contributors to our planet's hydrological cycle [1]. Over the open ocean away from coastal regions and high latitudes, impacts of river and ice melting are limited and evaporation-minus-precipitation (referred to as E-P thereafter) is the major freshwater flux forcing that, together with dynamical processes in the ocean, drives the variability of ocean salinity. Salinity is measured using satellite colour imagery and then using algorithms to convert this data into salinity units. There are two types of studies used to correlate satellite-measured radiance or reflectance with salinity using different approaches, such as multilinear regression. The second type uses the apparent inversion of salinity from the absorption of coloured dissolved organic matter (CDOM) that can be retrieved from ocean colour satellite products, particularly close to the shore. This apparent inversion can be used in models to derive actual salinity, given that actual salinity is known in a certain area [2]. For example, Zhao et

\footnotetext{
* CONTACT: Obianyo.jude@mouau.edu.ng

DOI: http://dx.doi.org/10.28991/esj-2019-01188
}

(C) 2019 by the authors. Licensee ESJ, Italy. This is an open access article under the terms and conditions of the Creative Commons Attribution (CC-BY) license (https://creativecommons.org/licenses/by/4.0/). 
al. (2017) [3] used reflectance data from bands 1 to 7 of Landsat 8, and correlations with surface data, to measure sea salinity in the Arabian Gulf. The profound effects of changing salinity on ocean mixing, water mass formation, and ocean general circulation have been reported in many observational studies [e.g. 4-7]. It has long been known that, on a long-term mean basis, the spatial distribution of near-surface salinity is closely related to the spatial pattern of E-P. High salinities are located in the subtropical oceans where evaporation exceeds precipitation, and low salinities are located in the tropical and high latitudes where precipitation exceeds evaporation. Given that ocean salinity is a better observed variable than evaporation and/or precipitation, the concept of using the oceans as a rain gauge for the global water cycle has been proposed. Several attempts have been made in the past decades. For instance, Elliot (1974) [8] used data collected during the Barbados Oceanographic and Meteorological Experiment (BOMEX) in the summer of 1969 and attempted to evaluate the total precipitation from the observed salinity changes. However, the results were inconclusive. In the absence of rain events, the change in salinity within the top $10 \mathrm{~m}$ is of the same magnitude as the salinity fluctuation caused by the dilution of rainfall ( $0.15 \mathrm{psu})$.

More recently, Yaremchuk (2006) [9] attempted to improve the monthly precipitation climatology in the monsoon heavy-rain regions by enforcing the surface salinity of the World Ocean Atlas 2005 (WOA05) [10] as a constraint for an ocean model. By assuming that the model errors are much smaller. The promise of using ocean salinity observations to understand the change in the ocean water cycle has gained increasing attention in recent years. There are two main drivers behind this trend. One is the rapid expansion of the salinity archive, thanks to the technology advancement and extensive international collaborations that have significantly advanced in in-situ and satellite observing systems. The other is the need to better understand and quantify the change of the global water cycle in a changing climate. There are currently more than 3200 ARGO free-floating profiling floats distributed throughout the world's oceans, providing temperature and salinity profiles around the globe for the past ten years $[11,12]$. There are also two salinity satellite missions; one is the Soil Moisture and Ocean Salinity Mission (SMOS) by the European Space Agency, which was launched in November 2009 and has begun its operational life transmitting data. The other is the NASA Aquarius mission which was launched in June 2011 aboard the Argentine SAC-D spacecraft. The monitoring of surface salinity from space, together with the provision of regular surface and sub-surface salinity profiles from in-situ observing systems, provides not only a key constraint on the balance of the freshwater input over the ocean, but also a valid reference measure to understand the strength of the water cycle [13]. It has long been known that evaporation from a free water surface is reduced by salinity. Several investigators have presented the results of experimental determinations of the reduction in evaporation with increasing salinity

Lee (1927) [14] compared the evaporation from distilled water with evaporation from Owens Lake brine of varying specific gravities, and presented a chart showing that up to a certain limit the ratio of the brine to that of distilled water decreased about $1 \%$ for a change in specific gravity of 0.01 . Young (1947) [15] presented the results of experiments using varying concentrations of sodium chloride, and his findings did not vary greatly from those of Lee (1927) [14]. Salinity is the ocean signature of the global water cycle [16]. Salinity is one of the most important parameters among the water quality parameters that affect the hydrological cycle and the interaction between the water surface and the atmosphere. It has a great effect on the exchange of gases through the air-water interface. Salinity has a significant influence upon the surface specific humidity gradient as it decreases the surface vapour pressure; thus it affects the evaporation rate [17]. However, current atmospheric circulation models used in climatic studies still ignore its influence upon evaporation. An example of the importance of salinity and its influence on the global climate and water cycle is the "great salinity anomaly". In 1970, a large amount of less saline and low temperature water from the Arctic flowed into the northerly part of the North Atlantic via the Fraim Strait. It largely decreased the temperature of air in the northern Europe and influenced on the energy balance system and the evaporation rate on this region [4, 18]. Evaporation over a water body has an influential role in the hydrological cycle, as it is the common parameter in the energy and water balance equations. Knowing the amount of water evaporated from any water body into the atmosphere is a crucial step in different aspects of the management of water resources for different purposes such as wetland management, design of water storage reservoirs, and surface water system studies [19-21].

During the last decades, as a result of high evaporation and low recharge, severe water quality problems related to salinity have occurred in many lakes in different climatic regions around the world such as the Quaroun Lake in Egypt. Increased salinity resulted in change of the lakes hydrological cycle and destroying the aquatic life of these lakes. Many studies were developed to estimate the evaporation rate and control the salinity in the lake [22, 23]. In a study of the influence of evaporation and rainfall on a supra tidal groundwater dynamics and salinity structure in a sandy beach [24], found that evaporation significantly increased pore water salinity, up to $85 \mathrm{~g} / 1$ within the shallow layer, approximately $10 \mathrm{~cm}$ below the beach surface. The induced density gradient generated salt fingers near the beach surface, which caused local groundwater circulation (i.e. fingering flow). However, unlike inland aquifers, the salt fingering was significantly diminished by tidal action that prompted the horizontal mixing of salt in the beach. The Dead Sea, a large hyper saline lake, is fed by onshore freshwater springs that form local diluted buoyant plumes, offering a unique opportunity to explore this effect, surface heat fluxes, micrometeorological variables, water temperature and salinity profiles were measured simultaneously and directly over the salty lake and over a region of diluted buoyant plume. Relatively close meteorological conditions prevailed in the two regions; however, surface water salinity was significantly different. 
Evaporation rate from the diluted plume was occasionally three times larger than that of the main salty lake. In the open lake, where salinity was uniform with depth, increased wind speed resulted in increased evaporation rate, as expected. However, in the buoyant plume where diluted brine floats over the hyper saline brine, wind speed above a threshold value $\left(\cong 4 \mathrm{~m} \mathrm{~S}^{-1}\right.$ ) caused a sharp decrease in evaporation probably due to mixing of the stratified plume and a consequent increase in the surface water salinity [25]. Evaporation plays a major role in lake systems, as it affects the water, energy and solutes budgets. Water salinity reduces evaporation, and as a result affects the energy budget of the lake, including stored heat [26]. Changes in the surface salinity due to climate change, such as increased rainfall or enhanced melting of the Greenland ice sheet, could disrupt the Atlantic Meridional Overturning Circulation (AMOC) by adding fresh water, making the sea water less dense and unable to sink. Such changes would affect both the climate and the sea levels of the regions surrounding the North Atlantic [27].

\section{2- Materials and Method}

The salts for this study were Magnesium Sulphate $\left(\mathrm{MgSO}_{4}\right)$, Sodium Hydroxide $(\mathrm{NaOH})$, Sodium Chloride $(\mathrm{NaCl})$, Ammonium Chloride $\left(\mathrm{NH}_{4} \mathrm{Cl}\right)$ and Potassium Nitrate $\left(\mathrm{KNO}_{3}\right)$ respectively. For concentration of salts, $0.04,0.08,0.12$, $0.16,0.20$ and $0.24 \mathrm{~g} / \mathrm{cm}^{3}$ solutions of these salts were prepared by dissolving 20,40, 60, 80, 100 and $120 \mathrm{~g}$ of these salts in $500 \mathrm{~cm}^{3}$ of distilled water. Seven evaporation cans were used in this study, one of the evaporation cans contained only $500 \mathrm{~cm}^{3}$ of distilled water and served as the control experiment. The dimensions of the evaporation can are 10.553 $\mathrm{cm}$ diameter and a depth of $8.0 \mathrm{~cm}$ which gives a total volume of $700 \mathrm{~cm}^{3}$. All the evaporation cans were stored under room temperature to avoid absorption of moisture from the atmosphere. Evaporation was allowed to take place and were measured at 24 hours intervals for 14 days. Evaporation from the cans were determined with Citizen $(R)$ electronic weighing balance, which is the difference between the initial weight of the evaporation can plus salt solution and that of the following day being the final weight. Evaporation retardation factor in the salt solutions were determined from the Equation 1.

$$
R_{f}=E_{s} / E_{c}
$$

Where $R_{f}$ is the evaporation retardation factor, $E_{s}$ is cumulative evaporation of salt at $0.24 \mathrm{~g} / \mathrm{cm}^{3}$ concentration and $E_{c}$ is the cumulative evaporation for control experiment at the same concentration.

\section{3- Results and Discussion}

\section{3-1-Results}

The presence of salts in water bodies such as rivers, oceans, streams and lakes creates salinity and retards evaporation from these water bodies, which consequently affects the climate. Knowledge of salinity in water bodies could help meteorological and climate change studies together with prediction of rainfall events. The results of this study showed the capacity to which the presence of different salts could retard evaporation from surfaces of water bodies. Tables 1 to 5 presented the relationships between cumulative evaporation and time for different salts such as Magnesium sulphate, Sodium Hydroxide, Sodium Chloride, Ammonium Chloride and Potassium Nitrate respectively. Table 6 is showed the relationship between evaporation retardation factors and time at $0.24 \mathrm{~g} / \mathrm{cm}^{3}$ concentration. Figures 1 to 5 represented the plots between cumulative evaporation and time for the salts while Figure 6 is the plot of the cumulative evaporation against time at ultimate dosage of $0.24 \mathrm{~g} / \mathrm{cm}^{3}$. In Figure 7, the plot of evaporation retardation factors against time for salts was presented.

Table 1. Relationship between cumulative evaporation and time for Magnesium Sulphate.

\begin{tabular}{|c|c|c|c|c|c|c|c|}
\hline \multirow{2}{*}{$\begin{array}{l}\text { Time } \\
\text { (days) }\end{array}$} & \multirow{2}{*}{$\begin{array}{c}\text { Control } \\
0.0\left(\mathrm{~g} / \mathrm{cm}^{3}\right)\end{array}$} & \multicolumn{6}{|c|}{ Concentration of salt $\left(\mathrm{g} / \mathrm{cm}^{\mathbf{3}}\right)$} \\
\hline & & 0.04 & 0.08 & 0.12 & 0.16 & 0.20 & 0.24 \\
\hline 0 & 0 & 0 & 0 & 0 & 0 & 0 & 0 \\
\hline 1 & 50 & 37 & 34 & 29 & 35 & 34 & 30 \\
\hline 2 & 130 & 91 & 93 & 85 & 86 & 88 & 90 \\
\hline 3 & 170 & 155 & 163 & 152 & 158 & 163 & 158 \\
\hline 4 & 225 & 202 & 194 & 198 & 202 & 203 & 195 \\
\hline 5 & 270 & 243 & 247 & 253 & 257 & 259 & 241 \\
\hline 6 & 300 & 266 & 271 & 271 & 278 & 279 & 260 \\
\hline 7 & 354 & 318 & 325 & 328 & 334 & 323 & 307 \\
\hline 8 & 434 & 339 & 345 & 349 & 355 & 342 & 327 \\
\hline 9 & 487 & 393 & 389 & 393 & 395 & 384 & 362 \\
\hline 10 & 500 & 439 & 438 & 441 & 429 & 417 & 400 \\
\hline 11 & - & 484 & 482 & 482 & 465 & 444 & 436 \\
\hline 12 & - & 498 & 499 & 491 & 479 & 457 & 453 \\
\hline 13 & - & 500 & 500 & 497 & 491 & 465 & 469 \\
\hline 14 & - & - & - & 500 & 492 & 471 & 476 \\
\hline
\end{tabular}


Table 2. Relationship between cumulative evaporation and time for Sodium Hydroxide.

\begin{tabular}{|c|c|c|c|c|c|c|c|}
\hline \multirow{2}{*}{$\begin{array}{l}\text { Time } \\
\text { (days) }\end{array}$} & \multirow{2}{*}{$\begin{array}{c}\text { Control } \\
0.0\left(\mathrm{~g} / \mathrm{cm}^{3}\right)\end{array}$} & \multicolumn{6}{|c|}{ Concentration of salt $\left(\mathrm{g} / \mathrm{cm}^{\mathbf{3}}\right)$} \\
\hline & & 0.04 & 0.08 & 0.12 & 0.16 & 0.20 & 0.24 \\
\hline 0 & 0 & 0 & 0 & 0 & 0 & 0 & 0 \\
\hline 1 & 50 & 42 & 41 & 42 & 40 & 33 & 37 \\
\hline 2 & 130 & 111 & 97 & 98 & 95 & 81 & 70 \\
\hline 3 & 170 & 188 & 175 & 165 & 159 & 137 & 120 \\
\hline 4 & 225 & 226 & 209 & 193 & 189 & 161 & 134 \\
\hline 5 & 270 & 278 & 262 & 238 & 226 & 198 & 178 \\
\hline 6 & 300 & 296 & 280 & 249 & 235 & 205 & 191 \\
\hline 7 & 354 & 334 & 308 & 276 & 257 & 223 & 210 \\
\hline 8 & 434 & 351 & 321 & 287 & 264 & 231 & 221 \\
\hline 9 & 487 & 383 & 353 & 317 & 290 & 256 & 238 \\
\hline 10 & 500 & 418 & 371 & 339 & 299 & 263 & 245 \\
\hline 11 & - & 439 & 395 & 362 & 320 & 286 & 267 \\
\hline 12 & - & 453 & 409 & 373 & 331 & 295 & 280 \\
\hline 13 & - & 461 & 427 & 383 & 352 & 307 & 297 \\
\hline 14 & - & 467 & 438 & 393 & 391 & 318 & 306 \\
\hline
\end{tabular}

Table 3. Relationship between cumulative evaporation and time for Sodium Chloride.

\begin{tabular}{cccccccc}
\hline \multirow{2}{*}{$\begin{array}{c}\text { Time } \\
(\mathbf{d a y s})\end{array}$} & $\begin{array}{c}\text { Control } \\
\mathbf{0 . 0}\left(\mathbf{g} / \mathbf{c m}^{\mathbf{3}}\right)\end{array}$ & $\mathbf{0 . 0 4}$ & $\mathbf{0 . 0 8}$ & $\mathbf{0 . 1 2}$ & $\mathbf{0 . 1 6}$ & $\mathbf{0 . 2 0}$ & $\mathbf{0 . 2 4}$ \\
\hline 0 & 0 & 0 & 0 & 0 & 0 & 0 & 0 \\
1 & 50 & 41 & 34 & 29 & 30 & 33 & 24 \\
2 & 130 & 105 & 96 & 93 & 95 & 82 & 86 \\
3 & 170 & 179 & 167 & 175 & 175 & 153 & 156 \\
4 & 225 & 217 & 200 & 202 & 200 & 188 & 187 \\
5 & 270 & 267 & 240 & 243 & 240 & 240 & 232 \\
6 & 300 & 290 & 260 & 265 & 258 & 249 & 250 \\
7 & 354 & 323 & 289 & 293 & 283 & 280 & 280 \\
8 & 434 & 343 & 305 & 304 & 298 & 293 & 294 \\
9 & 487 & 378 & 345 & 349 & 346 & 330 & 333 \\
10 & 500 & 408 & 375 & 383 & 379 & 367 & 356 \\
11 & - & 458 & 445 & 446 & 438 & 412 & 408 \\
12 & - & 471 & 487 & 486 & 477 & 442 & 435 \\
13 & - & 488 & 500 & 500 & 494 & 459 & 451 \\
14 & - & 495 & - & - & 500 & 477 & 464 \\
\hline
\end{tabular}

Table 4. Relationship between cumulative evaporation and time for Ammonium Chloride.

\begin{tabular}{cccccccc}
\hline \multirow{2}{*}{$\begin{array}{c}\text { Time } \\
\text { (days) }\end{array}$} & $\begin{array}{c}\text { Control } \\
\mathbf{0 . 0}\left(\mathbf{g} / \mathbf{c m}^{\mathbf{3}}\right)\end{array}$ & $\mathbf{0 . 0 4}$ & $\mathbf{0 . 0 8}$ & $\mathbf{0 . 1 2}$ & $\mathbf{0 . 1 6}$ & $\mathbf{0 . 2 0}$ & $\mathbf{0 . 2 4}$ \\
\hline 0 & 0 & 0 & 0 & 0 & 0 & 0 & 0 \\
1 & 50 & 44 & 41 & 29 & 37 & 33 & 26 \\
2 & 130 & 109 & 108 & 101 & 107 & 97 & 92 \\
3 & 170 & 196 & 184 & 170 & 179 & 178 & 155 \\
4 & 225 & 231 & 219 & 205 & 209 & 209 & 188 \\
5 & 270 & 287 & 272 & 264 & 263 & 253 & 240 \\
6 & 300 & 308 & 297 & 279 & 276 & 271 & 252 \\
7 & 354 & 350 & 336 & 311 & 310 & 309 & 281 \\
8 & 434 & 372 & 359 & 331 & 333 & 332 & 305 \\
9 & 487 & 416 & 414 & 407 & 403 & 390 & 350 \\
10 & 500 & 452 & 451 & 452 & 450 & 431 & 410 \\
11 & - & 488 & 492 & 488 & 486 & 469 & 450 \\
12 & - & 499 & 500 & 496 & 495 & 486 & 483 \\
13 & - & 500 & - & 500 & 500 & 494 & 497 \\
14 & - & - & - & - & - & 500 & 499 \\
\hline
\end{tabular}


Table 5. Relationship between cumulative evaporation and time for Potassium Nitrate.

\begin{tabular}{cccccccc}
\hline \multirow{2}{*}{ Time (days) } & $\begin{array}{c}\text { Control } \\
\mathbf{0 . 0}\left(\mathbf{g} / \mathbf{c m}^{\mathbf{3}}\right)\end{array}$ & $\mathbf{0 . 0 4}$ & $\mathbf{0 . 0 8}$ & $\mathbf{0 . 1 2}$ & $\mathbf{0 . 1 6}$ & $\mathbf{0 . 2 0}$ & $\mathbf{0 . 2 4}$ \\
\cline { 3 - 7 } & 0 & 0 & 0 & 0 & 0 & 0 & 0 \\
1 & 50 & 30 & 36 & 29 & 31 & 38 & 35 \\
2 & 130 & 85 & 95 & 83 & 90 & 98 & 93 \\
3 & 170 & 157 & 163 & 162 & 161 & 164 & 160 \\
4 & 225 & 213 & 217 & 220 & 213 & 218 & 208 \\
5 & 270 & 281 & 277 & 272 & 264 & 279 & 258 \\
6 & 300 & 295 & 291 & 292 & 280 & 297 & 274 \\
7 & 354 & 319 & 326 & 330 & 317 & 332 & 310 \\
8 & 434 & 346 & 345 & 345 & 337 & 346 & 332 \\
9 & 487 & 393 & 393 & 390 & 395 & 393 & 375 \\
10 & 500 & 444 & 442 & 438 & 440 & 428 & 411 \\
11 & - & 489 & 491 & 493 & 495 & 490 & 465 \\
12 & - & 499 & 499 & 500 & 500 & 500 & 487 \\
13 & - & 500 & 500 & - & - & - & 497 \\
14 & - & - & - & - & - & - & 500 \\
\hline
\end{tabular}

Table 6. Relationship between evaporation retardation factors and time at $0.24 \mathrm{~g} / \mathrm{cm}^{3}$ concentration.

\begin{tabular}{cccccc}
\hline \multirow{2}{*}{$\begin{array}{c}\text { Time } \\
\text { (days) }\end{array}$} & \multicolumn{5}{c}{ Evaporation retardation factors at $\mathbf{0 . 2 4} \mathbf{g} / \mathbf{c m}^{\mathbf{3}}$ concentrations } \\
\cline { 2 - 6 } & $\mathbf{M g S O}_{\mathbf{4}}$ & $\mathbf{N a O H}$ & $\mathbf{N a C l}$ & $\mathbf{N H}_{\mathbf{4}} \mathbf{C l}$ & $\mathbf{K N O}_{\mathbf{3}}$ \\
\hline 0 & 0 & 0 & 0 & 0 & 0 \\
1 & 0.6000 & 0.7400 & 0.4800 & 0.5200 & 0.7000 \\
2 & 0.6923 & 0.5385 & 0.6615 & 0.7077 & 0.7154 \\
3 & 0.9294 & 0.7059 & 0.9176 & 0.9118 & 0.9412 \\
4 & 0.8667 & 0.5956 & 0.8311 & 0.8356 & 0.9244 \\
5 & 0.8926 & 0.6593 & 0.8593 & 0.8889 & 0.9556 \\
6 & 0.8667 & 0.6367 & 0.8333 & 0.8400 & 0.9133 \\
7 & 0.8673 & 0.5932 & 0.7910 & 0.7938 & 0.8757 \\
8 & 0.7535 & 0.5092 & 0.6774 & 0.7028 & 0.7650 \\
9 & 0.7433 & 0.4887 & 0.6838 & 0.7187 & 0.7700 \\
10 & 0.8000 & 0.4900 & 0.7120 & 0.8200 & 0.8220 \\
\hline
\end{tabular}

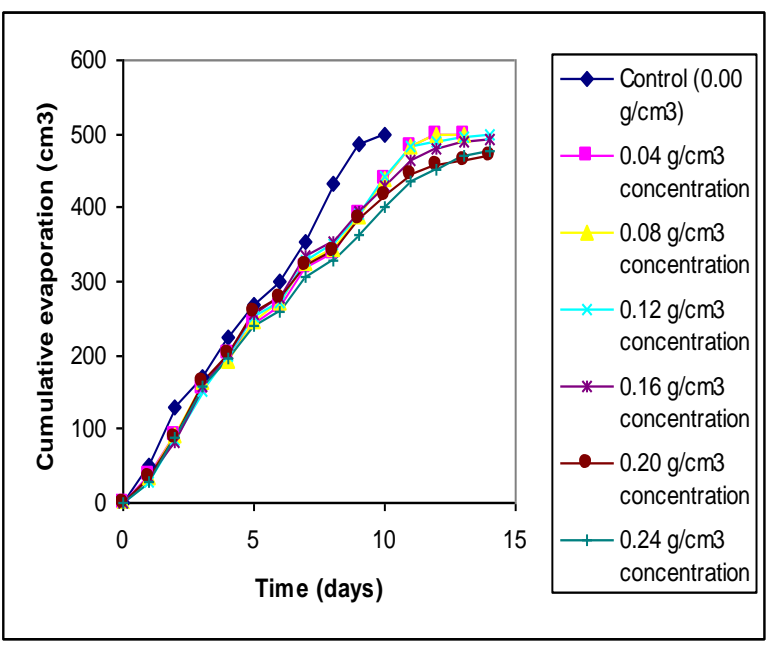

Figure 1. Relationship between cumulative evaporation and time for $\mathrm{MgSO}_{4}$ solution.

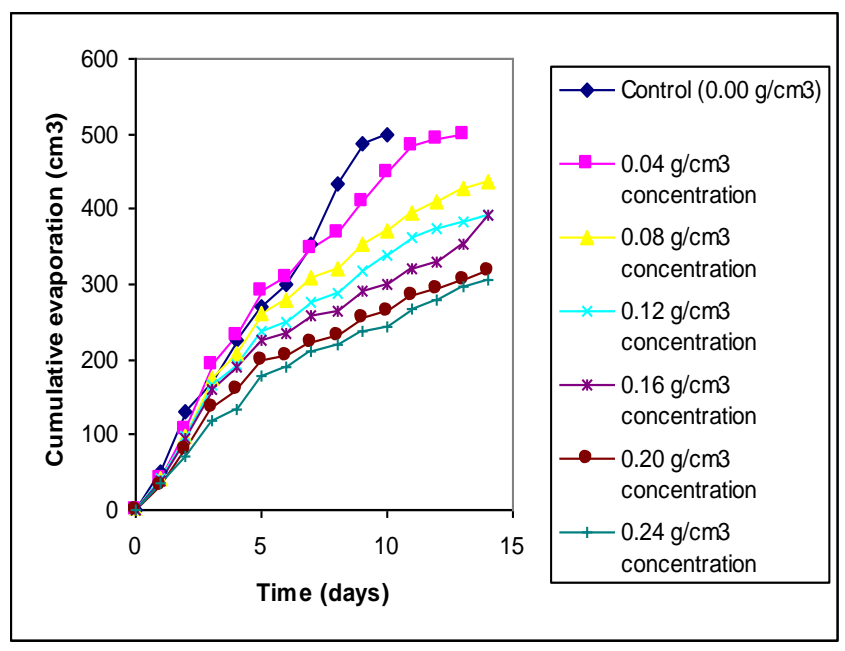

Figure 2. Relationship between cumulative evaporation and time for $\mathrm{NaOH}$ solution 


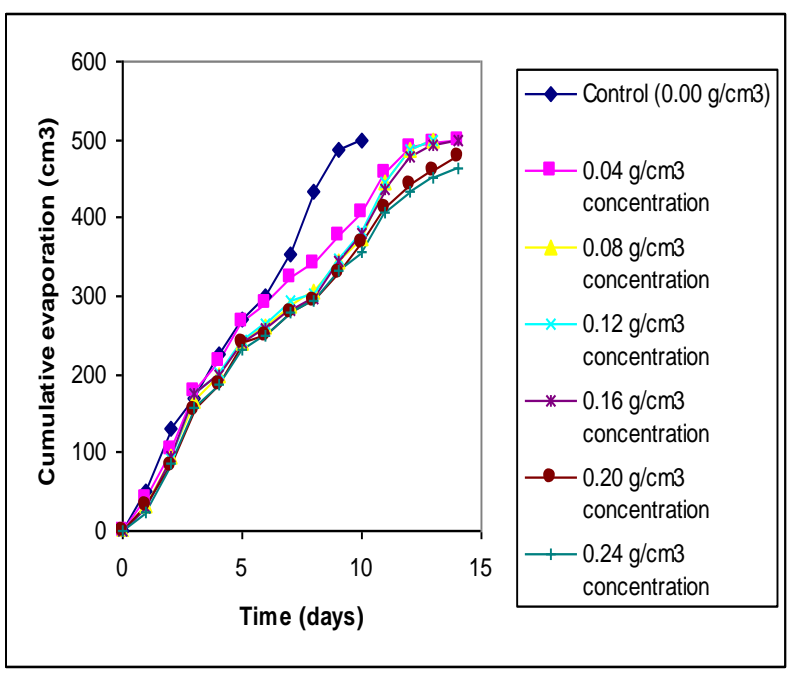

Figure 3. Relationship between cumulative evaporation and time for $\mathrm{NaCl}$ solution.

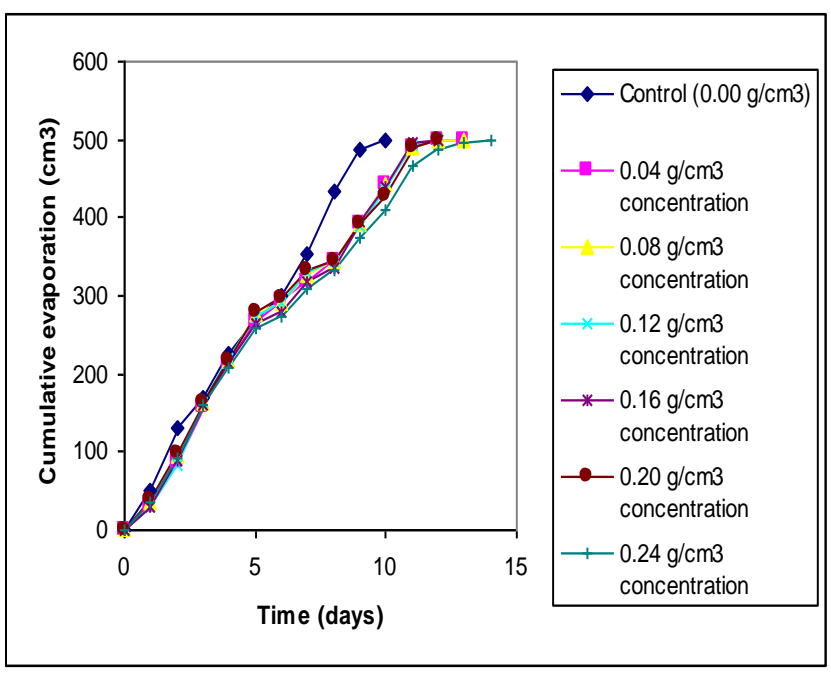

Figure 5. Relationship between cumulative evaporation and time for $\mathrm{KNO}_{3}$ solution

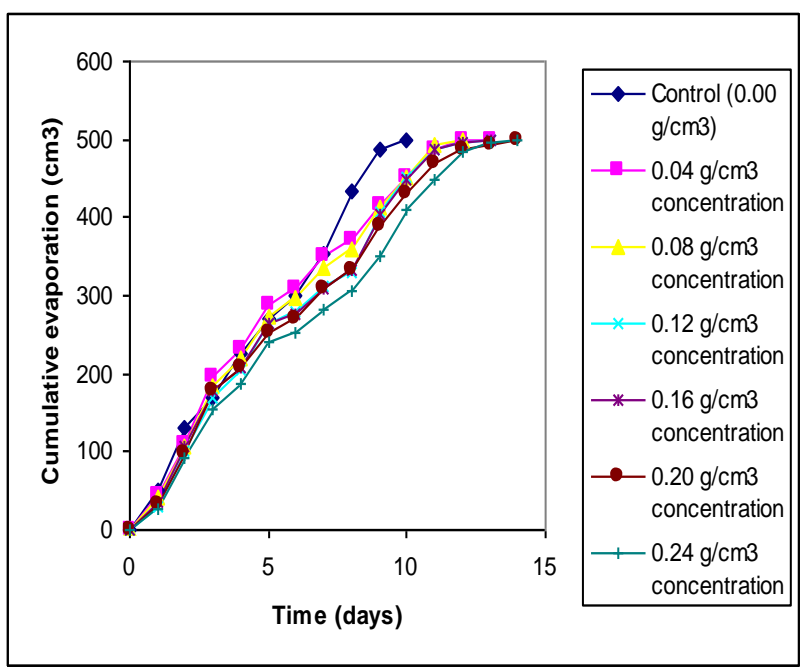

Figure 4. Relationship between cumulative evaporation and time for $\mathrm{NH}_{4} \mathrm{Cl}$ solution.

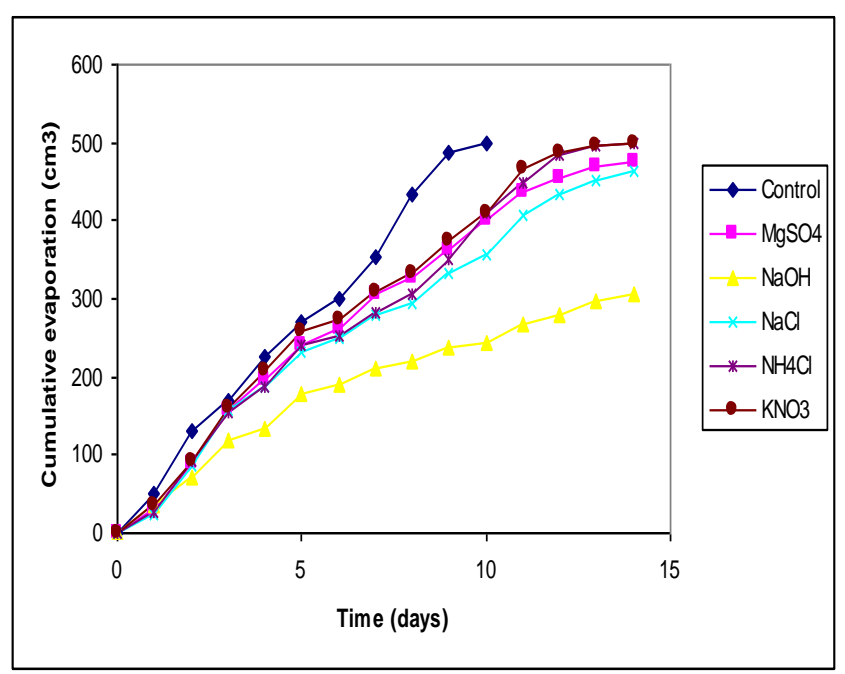

Figure 6. Plot of cumulative evaporation of salts against time at $0.24 \mathrm{~g} / \mathrm{cm}^{3}$ concentration

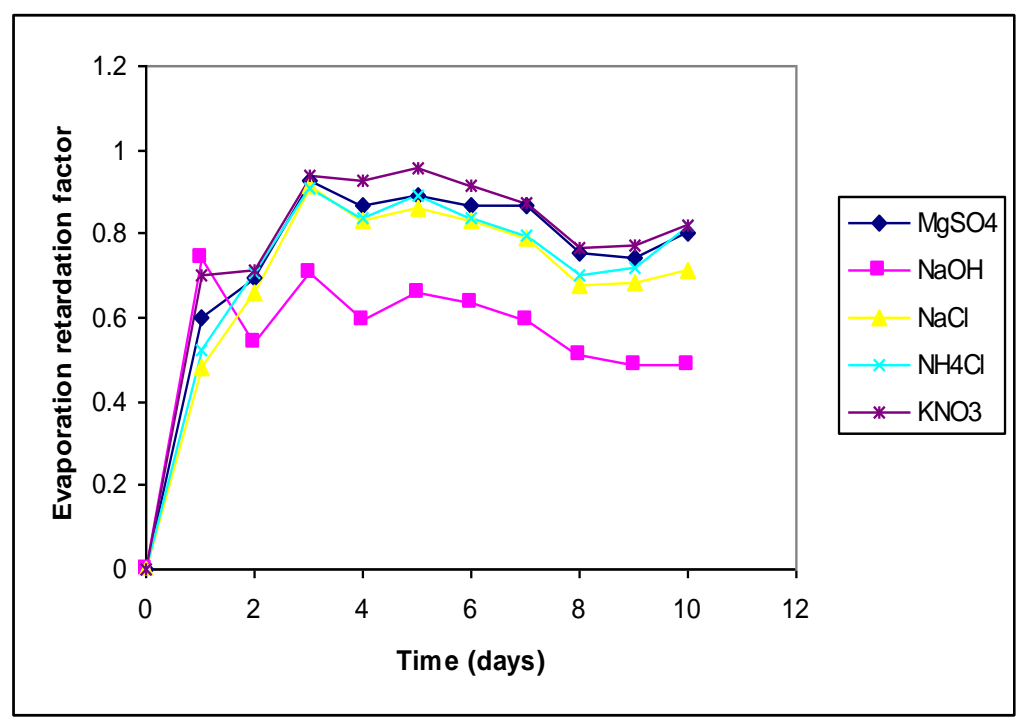

Figure 7. Plot of evaporation retardation factors against time for salts. 


\section{3-2- Discussion}

In the control experiment with distilled water, all the content evaporated on the 10th day, and for $\mathrm{MgSO}_{4}$, there was a decreasing trend in evaporation as the concentration of $\mathrm{MgSO}_{4}$ increased, except at 0.12 , which indicated increased evaporation next to $0.04 \mathrm{~g} / \mathrm{cm}^{3}$. For $\mathrm{NaOH}$, there was a consistent decrease in evaporation with concentration. This implies that the water budget will be affected by this trend. All the salts $\mathrm{MgSO}_{4}, \mathrm{NaOH}, \mathrm{NaCl}, \mathrm{NH}_{4} \mathrm{Cl}, \mathrm{and}_{\mathrm{KNO}}$ showed that as their concentrations increased, evaporation decreased. If the presence of these salts is indicated in water bodies, it will signal shifts and accelerations in the global rainfall and evaporation cycles. The greater the reduction of evaporation from water bodies as a result of salinity, the greater the impact in terms of global rainfall and the evaporation cycle. These changing patterns of salinity caused by these salts would be a clear symptom of climate change. These observed salinity changes as a result of $\mathrm{MgSO}_{4}, \mathrm{NaOH}, \mathrm{NaCl}, \mathrm{NH}_{4} \mathrm{Cl}$, and $\mathrm{KNO}_{3}$ and the relationship between salinity, rainfall, and evaporation in climate models would help to determine the strength of the water cycle. Looking at Table 6, which depicts evaporation retardation factors on different days on the 10th day, the retardation factors for $\mathrm{MgSO}_{4}$, $\mathrm{NaOH}, \mathrm{NaCl}, \mathrm{NH}_{4} \mathrm{Cl}$, and $\mathrm{KNO}_{3}$ were found to be $0.800,0.490,0.712,0.820$, and 0.822 , respectively. Ratios of evaporation retardation factors were 1:1.6372 for $\mathrm{NaOH}: \mathrm{MgSO}_{4} ; 1: 1.4531$ for Sodium Hydroxide: $\mathrm{NaCl}$; $1: 1.6735$ for $\mathrm{NaOH}$ : $\mathrm{NH} 4 \mathrm{Cl}$ and 1:1.6776 for $\mathrm{NaOH}: \mathrm{KNO}_{3}$. In Figure 6, it was observed that $\mathrm{KNO}_{3}$ experienced the highest evaporation, followed by $\mathrm{NH}_{4} \mathrm{Cl}, \mathrm{MgSO}_{4}, \mathrm{NaCl}$ and $\mathrm{NaOH}$ with the least evaporation, while Figure 7 is a plot of the relationship between evaporation retardation factors and time. In this, the results show that inhibition is highest with $\mathrm{NaOH}$, followed by $\mathrm{NaCL}, \mathrm{NH}_{4} \mathrm{Cl}, \mathrm{MgSO}_{4}$ and $\mathrm{KNO}_{3}$, with the least inhibition. From the hydrologic budget of any given system in which $\mathrm{I}-\mathrm{Q}=\mathrm{dS} / \mathrm{dt}$, where $\mathrm{I}$ is the inflow per unit time, $\mathrm{Q}$ is the outflow per unit time, and $\mathrm{dS} / \mathrm{dt}$ is the change in storage within the system per unit time, salinity will impact on the outflow parameter $\mathrm{Q}$ with a consequent reduction in evaporation, which would reduce precipitation. This situation would result since the formation of rain in the cloud is likely to be retarded. The retardation factor of 0.490 for $\mathrm{NaOH}$ indicates that the presence of this salt in oceans/lakes will retard evaporation by that factor and hence cause a higher tendency for rainfall since evaporation would be higher when compared with the presence of other salts in water bodies. The tendency for higher precipitation amounts in order of increasing magnitude will occur in $\mathrm{NaCl}$ with a retardation factor of $0.712, \mathrm{MgSO}_{4}$ and $\mathrm{NH}_{4} \mathrm{Cl}$ with retardation factors of 0.800 and 0.820 , respectively. The least is $\mathrm{KNO}_{3}$ with a retardation factor of 0.822 . Though the total quantity of water available to the earth is finite and indestructible, the presence of these salts in water bodies such as lakes, oceans, streams, etc., has a significant influence on the water cycle and, ultimately, climate change. Whether evaporation is highly influenced or not, it will have an impact on the climate based on the amount of retardation encountered at any point in time.

\section{4- Conclusion}

This study looked at the effect of salinity on evaporation and its probable effect on the water cycle. From the findings, it is concluded that salinity affects evaporation from free water bodies and surfaces and can impact the water cycle and ultimately lead to climate change. This is evident from the results of the study because it can be seen that evaporation is highest in distilled water, which served as the control experiment. This was followed by Potassium Nitrate, Ammonium Chloride, Magnesium Sulphate, Sodium Chloride and least with Sodium Hydroxide solutions. The study also showed that different salts have different capacities to inhibit evaporation from water bodies, as can be seen from the evaporation retardation factors, which were found to be $0.822,0.820,0.800,0.712$, and 0.490 for Potassium Nitrate, Ammonium Chloride, Magnesium Sulphate, Sodium Chloride, and Sodium Hydroxide. The salinity effect of these salts would have an impact on the water cycle and, consequently, the climate since, logically, a reduction in evaporation will reduce precipitation. Though the total quantity of water available to the earth is finite and indestructible, the presence of these salts in water bodies such as lakes, oceans, streams, etc., would have an influence on the water cycle and, ultimately, climate change.

\section{5- Conflict of Interest}

The authors declare no conflict of interest.

\section{6- References}

[1] Baumgarter, Albert, and Eberhard Reichel. The world water balance. Vol. 179. New York: Elsevier, 1975.

[2] Fingas, Merv. "Remote Sensing for Marine Management." World Seas: An Environmental Evaluation (2019): $103-119$. doi:10.1016/b978-0-12-805052-1.00005-x.

[3] Zhao, Jun, Marouane Temimi, and Hosni Ghedira. "Remotely Sensed Sea Surface Salinity in the Hyper-Saline Arabian Gulf: Application to Landsat 8 OLI Data." Estuarine, Coastal and Shelf Science 187 (March 2017): $168-177$. doi:10.1016/j.ecss.2017.01.008.

[4] Dickson, Robert R, Jens Meincke, Svend-Aage Malmberg, and Arthur J Lee. “The 'great Salinity Anomaly' in the Northern North Atlantic 1968-1982.” Progress in Oceanography 20, no. 2 (January 1988): 103-151. doi:10.1016/0079-6611(88)90049-3. 
[5] Lukas, Roger, and Eric Lindstrom. “The Mixed Layer of the Western Equatorial Pacific Ocean.” Journal of Geophysical Research 96, no. S01 (1991): 3343. doi:10.1029/90jc01951.

[6] Curry, Ruth, Bob Dickson, and Igor Yashayaev. "A Change in the Freshwater Balance of the Atlantic Ocean over the Past Four Decades.” Nature 426, no. 6968 (December 2003): 826-829. doi:10.1038/nature02206.

[7] Boyer, Timothy P., S. Levitus, J. I. Antonov, R. A. Locarnini, and H. E. Garcia. "Linear Trends in Salinity for the World Ocean, 1955-1998." Geophysical Research Letters 32, no. 1 (2005). doi:10.1029/2004g1021791.

[8] Elliott, Garry W. "Precipitation signatures in sea-surface-layer conditions during BOMEX." Journal of Physical Oceanography 4, no. 3 (1974): 498-501. doi:10.1175/1520-0485(1974)004<0498:psissl>2.0.co;2.

[9] Yaremchuk, M. “Sea Surface Salinity Constrains Rainfall Estimates over Tropical Oceans.” Geophysical Research Letters 33, no. 15 (2006). doi:10.1029/2006gl026582.

[10] Antonov, J.I., R.A. Locarnini, T.P. Boyer, A.V. Mishonov, and H.E. Garcia. World Ocean Atlas 2005, Vol. 2, Salinity, NOAA Atlas NESDIS, Vol. 62, edited by S. Levitus, 182pp., NOAA, Silver Spring, Md. (2006)

[11] Riser, Stephen, Li Ren, and Annie Wong. "Salinity in Argo: A Modern View of a Changing Ocean." Oceanography 21, no. 1 (March 1, 2008): 56-67. doi:10.5670/oceanog.2008.67.

[12] Roemmich, Dean, Gregory Johnson, Stephen Riser, Russ Davis, John Gilson, W. Breck Owens, Sylvia Garzoli, Claudia Schmid, and Mark Ignaszewski. "The Argo Program: Observing the Global Oceans with Profiling Floats." Oceanography 22, no. 2 (June 1, 2009): 34-43. doi:10.5670/oceanog.2009.36.

[13] Yu, Lisan. “A Global Relationship Between the Ocean Water Cycle and Near-Surface Salinity.” Journal of Geophysical Research 116, no. C10 (October 18, 2011). doi:10.1029/2010jc006937.

[14] Lee, Charles H. "Discussion of "Evaporation on reclamation projects" by IE Houk." Transactions of the American Society of Civil Engineers 90 (1927): 340-343.

[15] Young, Arthur A. “Some Recent Evaporation Investigations.” Transactions, American Geophysical Union 28, no. 2 (1947): 279. doi:10.1029/tr028i002p00279.

[16] Schmitt, Véronique, and François Lequeux. "SANS spectra and elastic plateau modulus in a charged wormlike micelles solution: effect of salt." Journal de Physique II 5, no. 2 (1995): 193-197. doi:10.1051/jp2:1995122.

[17] Font, Jordi, Adriano Camps, Andrés Borges, Manuel Martín-Neira, Jacqueline Boutin, Nicolas Reul, Yann H Kerr, Achim Hahne, and Susanne Mecklenburg. "SMOS: The Challenging Sea Surface Salinity Measurement from Space." Proceedings of the IEEE 98, no. 5 (May 2010): 649-665. doi:10.1109/jproc.2009.2033096.

[18] Belkin, Igor M., Sydney Levitus, John Antonov, and Svend-Aage Malmberg. “'Great Salinity Anomalies' in the North Atlantic.” Progress in Oceanography 41, no. 1 (January 1998): 1-68. doi:10.1016/s0079-6611(98)00015-9.

[19] Finch, J. W. “A Comparison Between Measured and Modelled Open Water Evaporation from a Reservoir in South-East England.” Hydrological Processes 15, no. 14 (2001): 2771-2778. doi:10.1002/hyp.267.

[20] Hudlow, M.D., R.K. Farnsworth and F.P. Richards. Evaporation into the atmosphere - Theory, history and applications Brutsaert, W.H. Bulletin of the American Meteorological Society, (1983): 64(5), 505 - 506.

[21] Mengistu, M.G., and M.J. Savage. "Open Water Evaporation Estimation for a Small Shallow Reservoir in Winter Using Surface Renewal.” Journal of Hydrology 380, no. 1-2 (January 2010): 27-35. doi:10.1016/j.jhydrol.2009.10.014.

[22] Ali, H., C. A. Madramootoo, and Dayem Abdel. "Management of Lake Qaroun for salinity control." Icid Journal 49, no. 1 (2000): $1-16$.

[23] Ali, H., C.A. Madramootoo, and S. Abdel Gwad. "Evaporation Model of Lake Qaroun as Influenced by Lake Salinity.” Irrigation and Drainage 50, no. 1 (2001): 9-17. doi:10.1002/ird.1.

[24] Geng, Xiaolong, and Michel C. Boufadel. "The Influence of Evaporation and Rainfall on Supratidal Groundwater Dynamics and Salinity Structure in a Sandy Beach.” Water Resources Research 53, no. 7 (July 2017): 6218-6238. doi:10.1002/2016wr020344.

[25] Mor, Z., S. Assouline, J. Tanny, I. M. Lensky, and N. G. Lensky. "Effect of Water Surface Salinity on Evaporation: The Case of a Diluted Buoyant Plume over the Dead Sea." Water Resources Research 54, no. 3 (March 2018): 1460-1475. doi:10.1002/2017wr021995.

[26] Hamdani, I., S. Assouline, J. Tanny, I.M. Lensky, I. Gertman, Z. Mor, and N.G. Lensky. "Seasonal and Diurnal Evaporation from a Deep Hypersaline Lake: The Dead Sea as a Case Study.” Journal of Hydrology 562 (July 2018): $155-167$. doi:10.1016/j.jhydrol.2018.04.057.

[27] Srokosz, M., and C. Banks. “Salinity from Space.” Weather 74, no. 1 (February 8, 2018): 3-8. doi:10.1002/wea.3161. 